\title{
VIROLOGIC AND IMMUNOLOGIC OUTCOME OF TREATMENT OF HIV INFECTION WITH A HERBAL CONCOCTION, A-ZAM, AMONG CLIENTS SEEKING HERBAL REMEDY IN NIGERIA
}

\author{
A. A. OnifadeE ${ }^{1,3}$, A. P. Jewell ${ }^{1}$ and A. B. Okesina ${ }^{2}$ \\ ${ }^{1}$ Faculty of Health \&Social Care Sciences, Kingston University \& St George's University of London, \\ London, UK, ${ }^{2}$ Osun State University, Osogbo, Osun State, Nigeria \\ ${ }^{3}$ College of Health Sciences, Igbinedion University, Okada, Edo State, Nigeria \\ E-mail: abdufattah sa@yahoo.com
}

\begin{abstract}
This study was to determine the effectiveness (CD4 count and viral load) of a safe herbal concoction, $\alpha$-Zam used by clients seeking herbal remedy for treatment of HIV infection in Nigeria. 51 patients taking $\alpha$-Zam as complementary and alternative therapy through the herbal therapist were studied for a period of 16 months. Preliminary medical and laboratory examinations using WHO and CDC criteria were done after confirmation of HIV infection by Western blotting in the nearest teaching hospitals to the residence of the patients. Regular visits were paid to the patients after commencement of the $\alpha$-Zam to assess the side-effects, drug interactions, toxicity and effectiveness of the herbal remedy. There was a statistical significance $(P<0.05)$ between pre-treatment and post-treatment CD4 count. $4(7.8 \%)$ of the patients had average increase in CD4 count of $262 \pm 16 \mathrm{cell} / \mu \mathrm{L}, 23$ (45.1\%) patients with average increase $310 \pm 16$ cell/ $\mu \mathrm{L}, 16$ (31.4\%) patients with average increase $456 \pm 25$ cell $/ \mu \mathrm{L}$ and $8(15.7 \%)$ patients with average increase $510 \pm 36 \mathrm{cell} / \mu \mathrm{L}$ ( \%) were at WHO staging I , II, III and IV respectively within 4 months on herbal therapy. There was very marked reduction in viral (HIV-RNA) load with 41 (80.4\%) and10 (19.6\%) HIV infected patients had undetectable viral load and $<1000 \mathrm{copies} / \mathrm{ml}$ respectively after the therapy. All symptoms and signs associated with HIV infection in all patients fully subsided within 4 weeks of commencement of $\alpha$-zam therapy and there was no evidence of negative drug interaction in those HIV patients using both the herbal and highly active anti-retroviral therapy (HAART). The study is in progress to determine periodic immunological outcomes of post therapy in all patients.
\end{abstract}

\section{Introduction}

There are many herbal medicines used for human immunodeficiency virus (HIV) infection in many parts of the world. Herbal remedies are herbs, herbal materials, herbal preparations and finished herbal products, that contain as active ingredients parts of plants, or plant materials, or combinations thereof used to treat a multitude of ailments throughout the world (WHO, 2002). It was estimated that about $80 \%$ of Africans used herbal remedies (WHO, 2002). The nature and severity of the illness prompted many to seek for options outside orthodox medicines especially when they are available in abundance. Herbal remedies may be used as complementary or alternative to orthodox medicines (King and Homsy, 1997).

In 2006, 63\% (about $2 / 3^{\text {rd }}$ ) of the people infected in the world live in sub-Saharan Africa, of which Nigeria has the largest population (UNAIDS, 2006). Thus, Nigeria is the third country in the world with largest population of people infected with HIV infection (WHO, 2005). Since the discovery of acquired immunodeficiency syndrome (AIDS) linked with HIV as the causative agent in early 1980s, Nigeria was not excluded from the scourge of this dreadful infection (Gallo et al., 1983). The use of herbal remedies for terminal illness is very common and the fact that HIV infection had no cure prompted many to seek for traditional medicines and spiritual solutions.

Thus Nigerians living with HIV infection since 1987 when the first case was reported in the country resulted to super-natural solutions (Abalaka, 2004). Despite the widely availability of non-expensive Highly Active Antiretroviral therapy (HAART), many HIV patients in Nigeria are desperately looking for quicker solution to the existing problems of long duration therapy by patronising herbal therapist. Campaigns by media houses and discouragement by medical practitioners had not stopped the herbal therapists from flourishing in HIV infection treatment business.

The effectiveness of herbal remedies in HIV infection is not doubtful. There are many herbal remedies that have been found to inhibit one or more steps in HIV replication (De Clereq, 2000; Kong et al 2003). Alkaloids derivatives herbal remedies (e.g. Ancistrocladus korupensis) from tropical liana plant inhibit reverse transcriptase and HIV induced cell fusion (Matthee et al., 1999). Pentosan poly-sulphate, a carbohydrate derivate inhibits HIV tat regulatory protein (p14) that strongly activates transcription of proviral DNA (Watson et al., 1999). A coumarin herbal remedy in form of canolides from tropical forest tree (Calophyllum lanigerum) was rated as non nucleoside reverse transcriptase inhibitor in potency 
(Dhamaratne et al., 2002). Despite the fact that sero-deconversion is very rare with HAART, some herbal remedies (e.g. Chinese medicines) have been documented in serodeconversion of HIV infected patients (Lu, 1997).

However, many HIV patients taking herbal remedies denied when asked by medical practitioners (Dwyer et al., 1995). The possible negative drug interaction between orthodox medicine and herb had been a major concern. St John's wort, herbal derived vitamins and garlic were documented to have caused negative drug interaction with anti-HIV drugs in some HIV patients (Dhalla et al., 2006; Nyika, 2007). However, many herbal medicines decreased drug resistance associated orthodox anti-retroviral drugs. Coumarins in combination therapy with nevirapine (component of HAART) decreased resistance due to HIV mutation (Dharmaratne et al., 2002; Yu et al., 2003).

There are many herbal remedies that are effective against HIV infection in Nigeria (Elujoba, 2005). Many of these documented herbal remedies act on the opportunistic infections caused by micro-organisms (Abere and Agoreyo, 2006; Elujoba, 2005). Baissea axillaries Hua, a popular herbal remedy in Nigeria used to treat many diseases was also effective in bacterial caused opportunistic infections in HIV patients (Abere and Agoreyo, 2006). However, neem leaves that are widely distributed in Nigeria increased the CD4 count and general well being significantly in HIV patients (Mbah et al., 2007). Thus there is a need to investigate the level of effectiveness of $\alpha$-Zam, an herbal remedy used by many HIV patients in Nigeria in patients taking it as alternative or complementary therapy.

\section{Materials and Methods}

This study got ethical approval from Faculty of Health and Social Care Sciences of Kingston University and St George's University of London thus leading to ATAS clearance in United Kingdom. Osun State University, Osogbo and Igbinedion University, Okada in Edo State also gave ethical approval to this study in Nigeria.

A-Zam -Is a safe herbal concoction that contained saponins (titerpene glycosides), tannins, cardenolides, alkaloids and possibly anthraquinones (Onifade et al., 2010). The adult table-spoon (about 10ml) of the concoction was diluted with about $50 \mathrm{ml}$ of warm water. The dosage was reduced to $5 \mathrm{ml}$ for paediatric patient. Each freshly constituted diluted medication was taken three times daily before food and normally for three months by patient at home (out-patient)

Patients were the HIV infected patients seeking herbal remedies as alternative or complementary therapy to HAART at $\alpha$-Zam therapist herbal centres.

Herbal centre:Herbal therapist confidence was gained and consent sought for using his patients and herbal remedy for this study. All the new patients coming for treatment on out-patient were recruited into the study after counselling and gaining their consents. The herbal therapist recruits patient via well treated 'former HIV patient' and their relatives. The herbal therapist dispensed a monthly $\alpha$-Zam dosage in 1 litre container for patient to come back for monitoring and review (outpatient).Each patient's contact and address was taken for monitoring, bi-monthly visits and repeat of medical and laboratory examinations when necessary.

Patients' selection: Power calculation was used to determine the sample size for this study. The pilot study was done. The patients were selected based on HIV positive test result from the diagnosed orthodox hospitals (government and private) however, only 51 patients that were confirmed (Western blot) at LAUTECH teaching hospital and Ahmadu Bello University Teaching Hospital and completed their herbal therapy within 5 months between September 2008 and December 2009 were considered for this study.

Patients: Blood sample for HIV confirmatory test in Nigerian Government owned tertiary institution laboratory (LAUTECH Teaching Hospital, Osogbo and Ahmadu Bello Teaching Hospital, Zaria) were done on all the patients in this study. All the samples were sent for laboratory analysis in teaching hospitals on out-patient basis. The viral (HIV-RNA) load was done at research centre via the LAUTECH teaching hospital while the CD4 count and other laboratory tests were done at both teaching hospitals used for this study. The study conducted preliminary examinations (laboratory and medical) using World Health Organisation (WHO, 2007) and Centre for Disease Control and Prevention (CDC, 1993) staging criteria and identified associated opportunistic infections or systemic diseases. The patients taking HAART with $\alpha$-Zam as complementary therapy were noted.

Medical examination: Skin, peripheral palpable lymph nodes, anaemia, body mass index, spleen, liver, kidney, chest, heart, including radiological investigations to ascertain the level of involvement of the organs

Laboratory- Immunology: CD4/CD8 count, B cell, Electrophoresis, ELISA and Western blotting techniques to confirm HIV infection.

Virology: viral (HIV-RNA) load using Polymerase Chain Reaction (PCR)

Haematology: Full Blood Count (FBC), blood film, Erythrocyte Sedimentation Rate (ESR)

Clinical chemistry: Electrolyte\& Urea (E\&U), Creatinine, Liver function test (LFT), C-reactive protein (CRP) and urinalysis.

Microbiology; blood microscopy, culture and sensitivity, sputum AAFB, urine microscopy and blood films for parasites when there was evidenced of infection

\section{Results}

The results are presented in Tables 1-4 and Figures 1-4. 
Table 1: showing the CD4 count and viral load of patients in WHO Staging I taking $\alpha$-Zam

\begin{tabular}{|c|c|c|c|c|c|c|c|c|}
\hline $\begin{array}{l}\text { Patient } \\
\text { no }\end{array}$ & Sex & Age & $\begin{array}{l}\text { Pre- } \\
\text { treatment } \\
\mathrm{CD} 4 \text { count } \\
(\text { cell } / \mu \mathrm{L})\end{array}$ & $\begin{array}{l}\text { Pre-treatment } \\
\text { HIV-RNA(viral } \\
\text { load) } \\
\text { copies/ml }\end{array}$ & $\begin{array}{l}\text { Post- } \\
\text { treatment } \\
\text { CD4 count } \\
\text { (cell } / \mu \mathrm{L})\end{array}$ & $\begin{array}{l}\text { Post-treatment } \\
\text { HIV-RNA(viral } \\
\text { load) copies/ml }\end{array}$ & $\begin{array}{l}\text { A-zam } \\
\text { or } \\
\text { HAART } \\
\text { or both }\end{array}$ & $\begin{array}{l}\text { Increase in } \\
\text { CD4 count }\end{array}$ \\
\hline $06 / z$ & $\mathrm{~F}$ & 30 & $400 \pm 31.3$ & $11000 \pm 4000$ & $700 \pm 50$ & undetectable & A-zam & $300 \pm 18.9$ \\
\hline $24 / Z$ & $\mathrm{~F}$ & 41 & $290 \pm 23.8$ & $21000 \pm 1000$ & $580 \pm 10$ & undetectable & A-zam & $290 \pm 13.9$ \\
\hline $17 / \mathrm{OS}$ & $\mathrm{F}$ & 29 & $280 \pm 28.8$ & $31000 \pm 6000$ & $540 \pm 30$ & undetectable & A-zam & $260 \pm 1.1$ \\
\hline $22 / Z$ & $\mathrm{~F}$ & 39 & $380 \pm 21.3$ & $13000 \pm 3000$ & $580 \pm 10$ & undetectable & A-zam & $200 \pm 31.1$ \\
\hline Mean & 1 & 34.75 & $337.5 \pm 27$ & $19000 \pm 3500$ & $600 \pm 25$ & & & $262.2 \pm 16$ \\
\hline
\end{tabular}

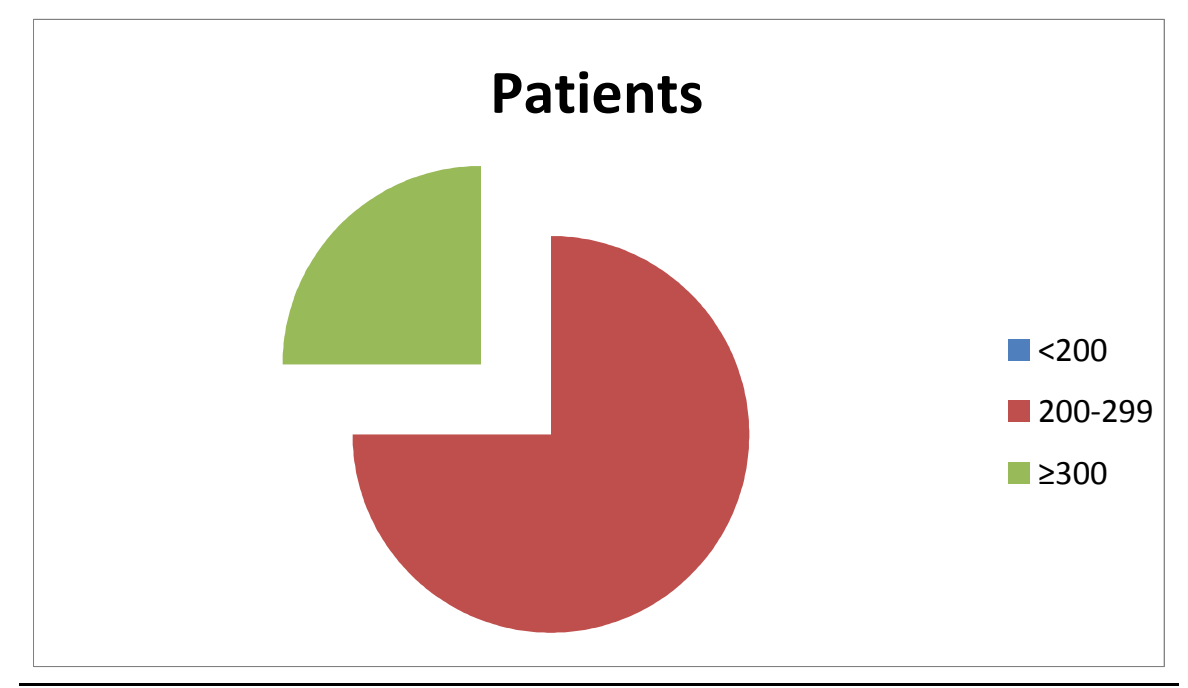

Figure 1: showing increase in CD4 count with the \% of WHO staging I HIV patients

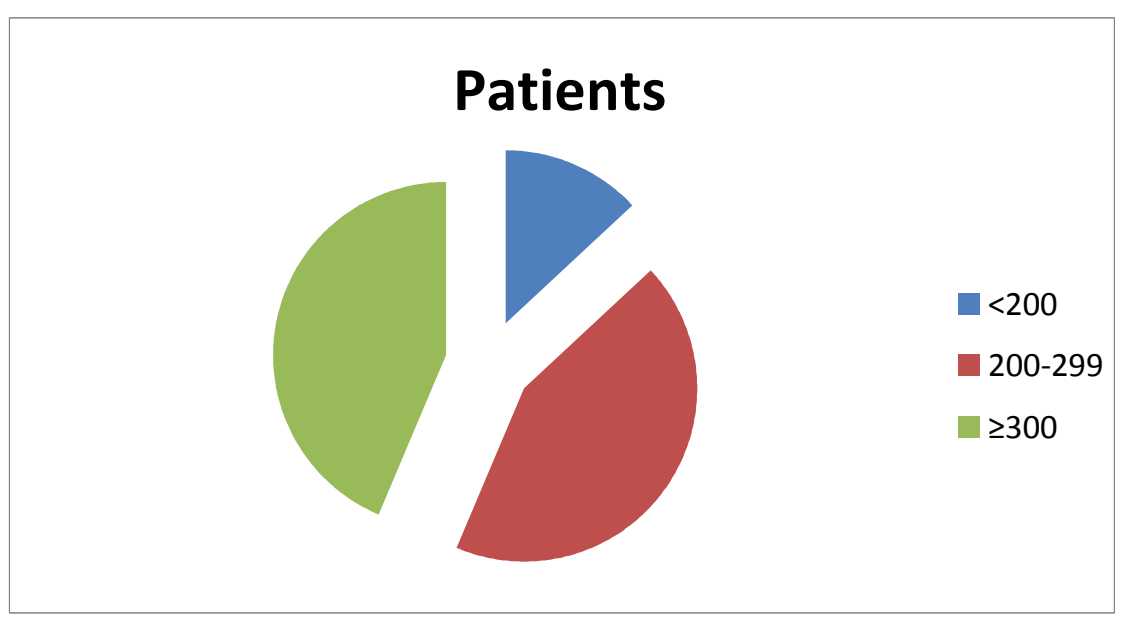

Figure 2: showing the increase inCD4 count with\% of HIV patients in WHO staging II taking $\alpha$-zam 
There was statistical significant difference $(P<0.05)$ between pre-treatment and post treatment $C D 4$ count in all the WHO staging groups of HIV patients using analysis of variance.

All the liver functions, electrolyte, urea and creatinine tests were normal during this study. All the haematological and microbiological parameters indicating possible presence of opportunistic infections became normal within a month in all patients in this study.

All the signs and symptoms associated with HIV infection presented by all patients in this study fully subsided within 3 weeks after commencement of the herbal concoction.

Table 2: showing the CD4 count and viral load of HIV patients in WHO Staging II taking $\alpha$-Zam

\begin{tabular}{|c|c|c|c|c|c|c|c|c|}
\hline $\begin{array}{l}\text { Patient } \\
\text { no }\end{array}$ & Sex & Age & $\begin{array}{l}\text { Pre- } \\
\text { treatment } \\
\text { CD4 count } \\
\text { (cells } / \mu \mathrm{L} \text { ) }\end{array}$ & $\begin{array}{l}\text { Pre- } \\
\text { treatment } \\
\text { HIV-RNA } \\
\text { (viral load) } \\
\text { copies/ml }\end{array}$ & $\begin{array}{l}\text { Post- } \\
\text { treatment } \\
\text { CD4 count } \\
\text { (cells } / \mu \mathrm{L} \text { ) }\end{array}$ & $\begin{array}{l}\text { Post-treatment } \\
\text { HIV-RNA (viral } \\
\text { load) copies/ml }\end{array}$ & $\begin{array}{l}\text { A-zam } \\
\text { or } \\
\text { HAART } \\
\text { or both }\end{array}$ & $\begin{array}{l}\text { Increase in } \\
\text { CD4 count }\end{array}$ \\
\hline $05 / z$ & $M$ & 38 & $260 \pm 0.2$ & $\begin{array}{l}44,000 \pm 333 \\
6\end{array}$ & $840 \pm 56$ & undetectable & A-zam & $580 \pm 56.2$ \\
\hline $10 / Z$ & $\mathrm{~F}$ & 44 & $320 \pm 12.3$ & $35000 \pm 1460$ & $800 \pm 47.7$ & undetectable & A-zam & $480 \pm 35.4$ \\
\hline $07 / z$ & $\mathrm{~F}$ & 30 & $280 \pm 4$ & $42000 \pm 1251$ & $750 \pm 37.3$ & undetectable & A-zam & $470 \pm 33.3$ \\
\hline 19/OS & $\mathrm{F}$ & 34 & $280 \pm 4$ & $32000 \pm 834$ & $740 \pm 35.2$ & undetectable & A-zam & $460 \pm 31.2$ \\
\hline $27 / z$ & $\mathrm{~F}$ & 39 & $260 \pm 0.2$ & $\begin{array}{l}41,000 \pm 271 \\
0\end{array}$ & $670 \pm 20.6$ & undetectable & A-zam & $410 \pm 20.8$ \\
\hline $28 / O S$ & $\mathrm{~F}$ & 40 & $220 \pm 8.6$ & $\begin{array}{l}31000 \pm 625 . \\
5\end{array}$ & $560 \pm 2.4$ & undetectable & A-zam & $340 \pm 6.2$ \\
\hline $26 / O S$ & $\mathrm{~F}$ & 42 & $220 \pm 8.6$ & $\begin{array}{l}29000 \pm 208 . \\
5\end{array}$ & $550 \pm 4.4$ & undetectable & A-zam & $330 \pm 4.1$ \\
\hline $23 / O S$ & $M$ & 34 & $260 \pm 0.2$ & $\begin{array}{l}25000 \pm 625 . \\
5\end{array}$ & $590 \pm 4.1$ & undetectable & A-zam & $330 \pm 4.1$ \\
\hline $18 / z$ & $\mathrm{~F}$ & 36 & $260 \pm 0.2$ & $\begin{array}{l}27000 \pm 208 . \\
5\end{array}$ & $570 \pm 0.3$ & undetectable & A-zam & $310 \pm 0.1$ \\
\hline $16 /$ OS & $\mathrm{F}$ & 32 & $230 \pm 6.5$ & $\begin{array}{l}35000 \pm 1459 \\
.6\end{array}$ & $530 \pm 8.6$ & undetectable & A-zam & $300 \pm 2.2$ \\
\hline $15 /$ OS & $\mathrm{F}$ & 41 & $270 \pm 1.9$ & $\begin{array}{l}29000 \pm 208 . \\
5\end{array}$ & $560 \pm 2.4$ & undetectable & both & $290 \pm 4.2$ \\
\hline $25 / O S$ & $M$ & 46 & $250 \pm 2.3$ & $\begin{array}{l}27000 \pm 208 . \\
5\end{array}$ & $540 \pm 6.5$ & undetectable & A-zam & $290 \pm 4.2$ \\
\hline $21 / z$ & $M$ & 41 & $280 \pm 4$ & $22000 \pm 1251$ & $570 \pm 0.3$ & undetectable & both & $290 \pm 4.2$ \\
\hline $28 / z$ & $M$ & 34 & $280 \pm 4$ & $15000 \pm 2710$ & $570 \pm 0.3$ & undetectable & A-zam & $290 \pm 4.2$ \\
\hline $19 / z$ & $\mathrm{~F}$ & 41 & $248 \pm 2.7$ & $30000 \pm 417$ & $530 \pm 8.6$ & undetectable & A-zam & $282 \pm 5.9$ \\
\hline $25 / z$ & $M$ & 37 & $230 \pm 6.5$ & $\begin{array}{l}31000 \pm 625 . \\
5\end{array}$ & $490 \pm 17$ & $<500$ & A-zam & $260 \pm 10.5$ \\
\hline $20 /$ OS & $\mathrm{F}$ & 26 & $270 \pm 1.9$ & $\begin{array}{l}33000 \pm 1042 \\
.6\end{array}$ & $520 \pm 10.7$ & undetectable & A-zam & $250 \pm 12.6$ \\
\hline $27 / z$ & $M$ & 28 & $290 \pm 6$ & $16000 \pm 2502$ & $540 \pm 6.5$ & undetectable & A-zam & $250 \pm 12.6$ \\
\hline $23 / z$ & $\mathrm{~F}$ & 38 & $240 \pm 4.4$ & $\begin{array}{l}27000 \pm 208 . \\
5\end{array}$ & $480 \pm 19.1$ & $<500$ & A-zam & $240 \pm 14.7$ \\
\hline $12 / O S$ & $M$ & 34 & $290 \pm 6.1$ & $36000 \pm 1668$ & $490 \pm 17$ & $<500$ & A-zam & $200 \pm 23$ \\
\hline $14 / Z$ & $\mathrm{~F}$ & 48 & $231 \pm 6.3$ & $\begin{array}{l}29000 \pm 208 . \\
5\end{array}$ & $400 \pm 35.7$ & $<500$ & both & $169 \pm 29.5$ \\
\hline $07 / O S$ & $M$ & 35 & $235 \pm 5.4$ & $\begin{array}{l}29000 \pm 208 . \\
5\end{array}$ & $400 \pm 35.7$ & $<1000$ & A-zam & $165 \pm 30.3$ \\
\hline $13 / Z$ & $\mathrm{~F}$ & 38 & $300 \pm 8.1$ & $21000 \pm 1460$ & $450 \pm 25.3$ & $<500$ & A-zam & $150 \pm 33.4$ \\
\hline
\end{tabular}




\begin{tabular}{|l|l|l|l|l|l|l|l|l|}
\hline Mean & 2 & 37.2 & $\mathbf{2 6 1} \pm 4.5$ & $28000 \pm 1387$ & $\mathbf{5 7 1 . 3} \pm 17.5$ & variable & & $\mathbf{3 1 0 . 3} \pm 15.8$ \\
\hline
\end{tabular}

Table 3: showing the CD4 and viral load of HIV patients in Stage III taking $\alpha$-Zam

\begin{tabular}{|c|c|c|c|c|c|c|c|c|}
\hline $\begin{array}{l}\text { Patient } \\
\text { no }\end{array}$ & Sex & Age & $\begin{array}{l}\text { Pre- } \\
\text { treatment } \\
\text { CD4 } \\
\text { (cell } / \mu \mathrm{L})\end{array}$ & $\begin{array}{l}\text { Pre-treatment } \\
\text { HIV-RNA(viral } \\
\text { load) } \\
\text { copies/ml }\end{array}$ & $\begin{array}{l}\text { Post- } \\
\text { treatment } \\
\text { CD4 } \\
\text { (cell } / \mu \mathrm{L})\end{array}$ & $\begin{array}{l}\text { Post-treatment } \\
\text { HIV-RNA(viral } \\
\text { load) copies/ml }\end{array}$ & $\begin{array}{l}\text { A-zam or } \\
\text { HAART } \\
\text { or } \\
\text { both }\end{array}$ & $\begin{array}{l}\text { Increase in } \\
\text { CD4 count }\end{array}$ \\
\hline $03 / 2$ & M & 10 & $240 \pm 1.7$ & $46000 \pm 938$ & $890 \pm 46.7$ & undetectable & A-zam & $650 \pm 48.4$ \\
\hline 05/OS & $\mathrm{F}$ & 32 & $270 \pm 5.9$ & $35000 \pm 1813$ & $890 \pm 46.7$ & undetectable & A-zam & $620 \pm 40.9$ \\
\hline $11 / Z$ & $\mathrm{~F}$ & 36 & $300 \pm 13.4$ & $39000 \pm 813$ & $890 \pm 46.7$ & undetectable & A-zam & $590 \pm 33.4$ \\
\hline $09 / 0 S$ & $\mathrm{~F}$ & 24 & $187 \pm 14.9$ & $50000 \pm 1938$ & $750 \pm 11.7$ & undetectable & A-zam & $563 \pm 26.6$ \\
\hline $02 / O S$ & $\mathrm{~F}$ & 23 & $320 \pm 18.4$ & $34000 \pm 2063$ & $880 \pm 44.2$ & undetectable & A-zam & $560 \pm 25.9$ \\
\hline $11 / \mathrm{OS}$ & $M$ & 43 & $232 \pm 3.7$ & $46000 \pm 938$ & $750 \pm 11.7$ & undetectable & A-zam & $518 \pm 15.4$ \\
\hline $08 / 0 S$ & $M$ & 36 & $245 \pm 0.4$ & $45000 \pm 688$ & $740 \pm 9.2$ & undetectable & A-zam & $495 \pm 9.6$ \\
\hline $22 / O S$ & $M$ & 46 & $250 \pm 0.9$ & $47000 \pm 1188$ & $690 \pm 3.4$ & undetectable & A-zam & $440 \pm 4.1$ \\
\hline $15 / Z$ & $\mathrm{~F}$ & 35 & $220 \pm 6.7$ & $49000 \pm 1688$ & $650 \pm 13.4$ & undetectable & A-zam & $430 \pm 6.6$ \\
\hline 04/OS & $\mathrm{M}$ & 39 & $270 \pm 5.9$ & $37000 \pm 1313$ & $690 \pm 3.4$ & undetectable & A-zam & $420 \pm 9.1$ \\
\hline $13 / \mathrm{OS}$ & $\mathrm{M}$ & 38 & $340 \pm 23.4$ & $33000 \pm 2313$ & $730 \pm 6.7$ & undetectable & A-zam & $390 \pm 16.6$ \\
\hline $16 / Z$ & $\mathrm{~F}$ & 25 & $240 \pm 1.7$ & $50000 \pm 1938$ & $620 \pm 20.8$ & undetectable & A-zam & $380 \pm 19.1$ \\
\hline $03 / 0 S$ & $M$ & 45 & $200 \pm 11.7$ & $38000 \pm 1063$ & $560 \pm 35.9$ & undetectable & A-zam & $360 \pm 24.1$ \\
\hline $20 / Z$ & $M$ & 37 & $210 \pm 9.2$ & $38000 \pm 1063$ & $520 \pm 45.9$ & undetectable & A-zam & $310 \pm 36.6$ \\
\hline 14/OS & $\mathrm{F}$ & 21 & $190 \pm 14.2$ & $54000 \pm 2938$ & $490 \pm 26.7$ & $<500$ & A-zam & $300 \pm 39.1$ \\
\hline $02 / z$ & $\mathrm{~F}$ & 8 & $232 \pm 3.7$ & $35000 \pm 1813$ & $510 \pm 48.4$ & $<500$ & A-zam & $278 \pm 44.6$ \\
\hline Mean & 3 & 31.1 & $246.6 \pm 8.5$ & $42250 \pm 1532$ & $703.3 \pm 29$ & variable & & $456.5 \pm 25$ \\
\hline
\end{tabular}

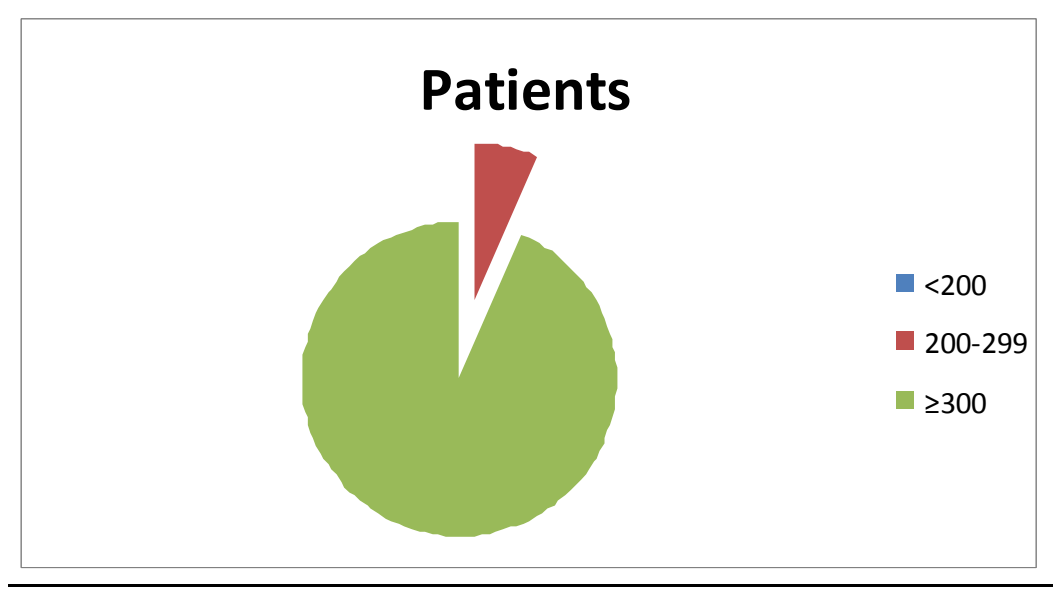

Figure 3: showing increase in CD4 count of HIV patients in WHO staging III taking $\alpha$-Zam

Table 4: showing the CD4 count and viral load of HIV patients in Stage IV taking $\alpha$-Zam

\begin{tabular}{|c|c|c|c|c|c|c|c|c|}
\hline $\begin{array}{l}\text { Patient } \\
\text { no }\end{array}$ & Sex & Age & $\begin{array}{l}\text { Pre- } \\
\text { treatment } \\
\text { CD4 count } \\
\text { (cell/ } \mu \mathrm{L}\end{array}$ & $\begin{array}{l}\text { Pre-treatment } \\
\text { HIV-RNA(viral } \\
\text { load) } \\
\text { copies/ml }\end{array}$ & $\begin{array}{l}\text { Post- } \\
\text { treatment } \\
\text { CD4 count } \\
(\text { cell } / \mu \mathrm{L})\end{array}$ & $\begin{array}{l}\text { Post-treatment } \\
\text { HIV-RNA(viral } \\
\text { load) copies/ml }\end{array}$ & $\begin{array}{l}\text { A-zam } \\
\text { or } \\
\text { HAART } \\
\text { or both }\end{array}$ & $\begin{array}{l}\text { Increase in } \\
\text { CD4 count }\end{array}$ \\
\hline $12 / z$ & $M$ & 29 & $187 \pm 10.4$ & $49000 \pm 574.5$ & $820 \pm 53.9$ & undetectable & both & $633 \pm 30.8$ \\
\hline $01 / \mathrm{OS}$ & $\mathrm{M}$ & 25 & $137 \pm 7.3$ & $52000 \pm 486.1$ & $760 \pm 32.7$ & undetectable & A-zam & $623 \pm 40$ \\
\hline $01 / z$ & $\mathrm{~F}$ & 7 & $137 \pm 7.3$ & $51000 \pm 132$ & $760 \pm 32.7$ & undetectable & A-zam & $623 \pm 40$ \\
\hline $08 / z$ & $M$ & 46 & $140 \pm 6.2$ & $53000 \pm 839.7$ & $750 \pm 29.2$ & undetectable & A-zam & $610 \pm 35.4$ \\
\hline $04 / Z$ & $M$ & 28 & $192 \pm 12.2$ & $50000 \pm 221$ & $780 \pm 39.8$ & undetectable & both & $588 \pm 27.6$ \\
\hline $21 / \mathrm{OS}$ & $\mathrm{F}$ & 31 & $178 \pm 7.2$ & $50000 \pm 221$ & $570 \pm 34.5$ & undetectable & A-zam & $392 \pm 41.7$ \\
\hline $09 / 2$ & $\mathrm{M}$ & 42 & $140 \pm 6.2$ & $51000 \pm 132.6$ & $450 \pm 76.9$ & $<500$ & A-zam & $310 \pm 70.7$ \\
\hline $06 /$ OS & $\mathrm{M}$ & 37 & $150 \pm 2.7$ & $49000 \pm 574.5$ & $450 \pm 76.9$ & $<1000$ & both & $300 \pm 74.2$ \\
\hline Mean & 4 & 30.6 & $157.6 \pm 7.4$ & $50625 \pm 397.7$ & $667.5 \pm 47$ & variable & & $509.9 \pm 36$ \\
\hline
\end{tabular}




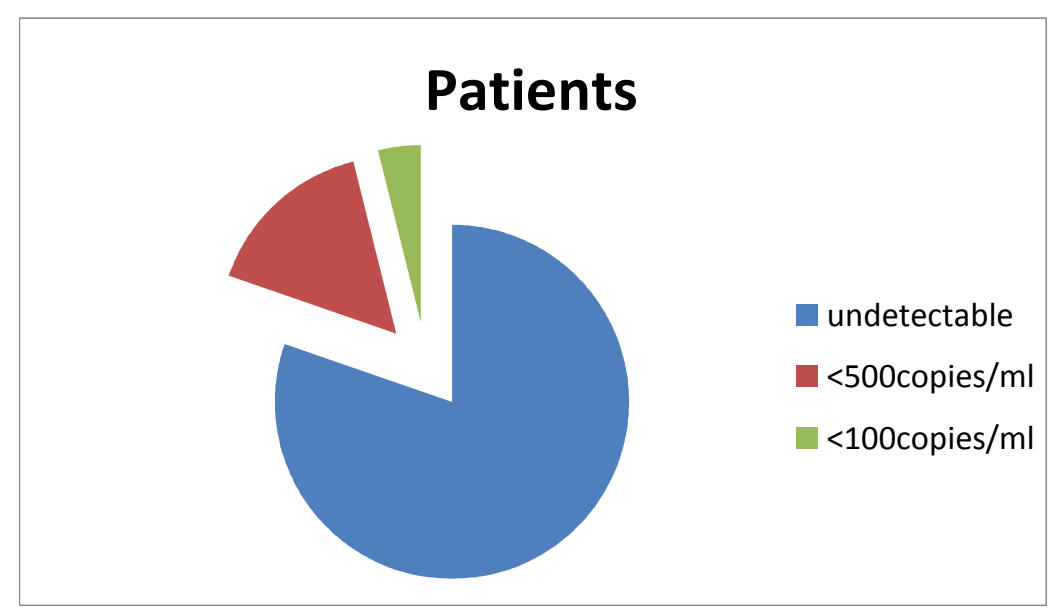

Figure 4: showing the summarised viral (HIV-RNA) load of all patients taking $\alpha$-Zam

\section{Discussion}

The role of herbal remedies in treatment of infections could not be over-emphasized. The herbal therapies are widely used by HIV patients and many denied when asked by orthodox practitioners (Dwyer et al., 1995 and Liu et al., 2009). In this study, 6 (11.8\%) declared the concurrent use of HAART with $\alpha$-Zam. Contrary to expectation of significant positive drug interaction, there was no sifnificant increase in CD4 count of all patients taking herbal concoction and HAART (complementary therapy) in this study. Nyika (2007) concluded in his study that some herbal remedies negatively interacted with orthodox anti-retroviral therapy but there was no noticeable harmful drug reaction in all patients taking complementary therapy in this study.

HIV infection had no orthodox curative therapy propelled many infected patients to desperately seek for alternative medicines. Thus any form of treatments was used to combat HIV infection. This manifested in this study with more patients declaring the use of both $\alpha$-zam and HAART at both clinical stages as seen in table II and IV. The WHO staging II and IV patients sought active treatment to HIV infection because further reduction in immunity would be dangerous to their health. However, the complementary therapy was more in patients at advanced HIV staging as seen in table IV with 3 of 8 patients using both $\alpha$-Zam and HAART. This result of this study supports the earlier studies that many HIV patients use complementary therapy (Liu et al., 2009).

There were more patients in clinical staging II (23 HIV patients) compared to other 3 stages in this study. The clinical WHO staging II HIV patients represented the active interventional stage in HIV infection. The reduction in immunity of HIV patients in at WHO staging II would make it easier for health practitioners, patients' relatives and patients to sought for full action to combat the deadly virus. The rapid disappearance of symptoms associated with HIV infection made many HIV patients relax in medication adherence thus slow increase in immunity manifesting withCD4 count as seen in table II. The increase in CD4 count of $<300 \mathrm{cell} / \mu \mathrm{L}$ in some HIV patients over the period of this study could be due to less adherence to medication by HIV patients. From figure II, 13 (56\%) of 23 HIV patients had less than average $300 \mathrm{cell} / \mu \mathrm{L}(75 \mathrm{cells} / \mu \mathrm{L}$ per month) increase inCD4 count unlike almost all patients in stage III and IV. This result was in support of earlier studies of HIV patients' poor adherence to anti-retroviral therapy (Duqqan et al., 2009; Minkoff et al., 2010; Talam et al., 2009).

A-zam, an herbal concoction significantly decreased the viral (HIV-RNA) load to undetectable level in many patients in this study. Despite there was low increase in CD4 count in staging I patients, the herbal remedy effectively reduced the HIV in blood circulation to undetectable level in 4 months on therapy. The low viraemia $(19,000)$ accounted for total reduction of HIV and total increase in CD4 count as seen in table and figure I. Tani et al. (2002) reported that herbal remedies improved the quality of life paediatric infected patients with increase in CD4 count and decrease in viral load over a period of 8years therapy, $\alpha$-zam reduced viral (HIV-RNA) load to undetectable level in many patients in shorter period in this study.

Contrary to expectation and earlier studies that many HIV patients presented late or at advance state, less (24 patients) were seen in this study (Ajayi et al 2009). The advanced stage of HIV infection manifested in patients at WHO staging III and IV with pre-treatment average CD4 count of 247 cell/ $\mu \mathrm{L}$ and 158 cell/ $\mu \mathrm{L}$ respectively. The high level of pretreatment viraemia (average 42,000 and 51000 copies $/ \mathrm{ml}$ respectively) and low level of pre-treatment CD4 count (247 and 157 cells $/ \mu \mathrm{L}$ ) as seen table III and IV resulted to rapid high increase in CD4 after treatment (457 and 510 cell/ $\mu \mathrm{L}$ respectively). Although many patients ( $94 \%$ and $100 \%$ of stage III and IV respectively) with advanced level of terminal infection would be expected to adhere to medication, all patients except one at stage III in this study had result that 
reflected adherence to herbal medication. Thus $\alpha$-zam effectiveness was affirmed by improved in clinical well beings of HIV patients at advanced stage.

UNAIDS/WHO (2005) estimated that many women in sub-Saharan were infected with HIV infection. There were many women taking herbal concoction for HIV infection in this study. All the patients at stage I were women and 28 of 51 HIV patients in this study were female. This showed that many HIV infected female patients were infected with HIV infection or sought for active HIV treatment at early stage (Adeleke et al., 2009). However, less women (2 of 6) patients were using complementary therapy and few female patients presented at advanced stage of HIV infection (WHO staging IV) in this study. Thus this study showed that many women infected with HIV infection used herbal remedies.

The effectiveness of herbal remedies led to their use in HIV infection as complementary or alternative in Nigeria. A-zam effectively controls HIV infection irrespective of clinical stage of the patient. This herbal concoction increased the CD4 count by average of 262, 310, 457 and 510 cells/ $\mu \mathrm{L}$ in WHO staging I, II, III, and IV patients respectively. The viral (HIVRNA) load drastically reduced from average of $19000 \mathrm{copies} / \mathrm{ml}$ to undetectable level in all patients in staging I and from 51000 copies $/ \mathrm{ml}$ to $<1000$ copies $/ \mathrm{ml}$ in stage IV HIV patients. The increase in CD4 count and decrease in viral load manifested with disappearance of symptoms and signs associated with HIV infection. Thus $\alpha$-zam herbal concoction has potent anti-HIV activities and could be developed for use like neem leaf and Baissea axillaries Hua products in HIV infection in Nigeria (Abere and Agoreyo 2006; Mbah et al., 2007). The CD4 count and viral (HIV-RNA) load results of this study supports earlier studies that some herbal remedies actively controlled HIV infection (Mills et al., 2005; Liu, 2007; Lu, 1997).

This study concluded that $\alpha$-Zam (herbal concoction) is an effective anti-HIV agent by causing significant increase in CD4 counts and marked decrease in viral (HIV-RNA) load with no remarkable harmful drug interaction with HAART and could be studied further for periodic immunologic and virologic post therapy in HIV patients taking it as alternative or complementary therapy.

\section{References}

1. Abalaka JOA (2004). Attempts to cure and prevent HIV/AIDS in central Nigeria between 1997 and 2002: opening a way to a vaccine-based solution to the problem? Vaccine 22(29-30):3819-3828

2. Abere TA and Agoreyo FO (2006). Antimicrobial and toxicological evaluation of the leaves of Baissea axillaries Hua used in the management of HIV/AIDS. BMC Complement Alter Med. 21; 6:22

3. Adeleke SI, Mukhtar-Yola M, Gwarzo GD (2009) Awareness and knowledge of mother-to-child transmission of HIV among mothers attending the pediatric HIV clinic, Kano, Nigeria. Ann Afr Med.; 8 (4):210-214.

4. Ajaiyeoba EO and Ogbole $\mathrm{OO}$ (2006). A phytotherapeutic approach to Nigerian anti-HIV and immunomodulatory drug discovery. African Journal of Medical Sciences 35 Suppl: 71-76.

5. Ajayi AO, Ajayi EA, Fasakin KA (2009) CD4+ T-Lymphocytes cell counts in adults with human immunodeficiency virus infection at the medical department of a tertiary health institution in Nigeria,. Ann Afr Med.; 8(4):257260.

6. CDC (1993). Revised Classification System for HIV Infection and Expanded Surveillance Case Definition for AIDS Among Adolescents and Adults MMWR 41 (RR-17).

7. De Clereq (2000). Current lead natural products for the chemotherapy of human immunodeficiency virus infection, Med. Res. Rev 20, 323-349.

8. Dhalla S, Chan KJ, Montaner JS, Hogg RS (2006). Complementary and alternative medicine use inBritish Columbia - a survey of HIV positive people on antiretroviral therapy. Complement Ther Clin Pract, 12(4):242-248.

9. Dharmaratne HRW, Tan GT, Marasinghe GPK, Pezzuto JM (2002). Inhibition of HIV-1 reverse transcriptase and HIV-1 replication by Calophyllum coumarins and xanthones. Planta Med; 68: 86-87.

10. Duggan JM, Locher A, Fink B, Okonta C and Chakraborty J (2009). Adherence to antiretroviral therapy: a survey of factors associated with medication usage. AIDS Care; 21(9):1141-1147

11. Dwyer JT, Salvato-Schille AM, Coulston A, Casey VA, Cooper WC and Selles WD (1995). The use of unconventional remedies among HIVpositive men living in California. J Assoc Nurses AIDS Care, 6:17-28.

12. Gallo R C, Sarin P S, Gelmann E P, Robert-Guroff M, Richardson E, Kalyanaraman V S, Mann D, Sidhu G D, Stahl R E, Zolla-Pazner S, Leibowitch J and Popovic M (1983). Isolation of human T- cell leukaemia virus in acquired immune deficiency syndrome (AIDS) Science 220:865-867.

13. Elujoba AA (2005). Medicinal plants and herbal medicines in the management of opportunistic infections in people living with HIV/AIDS, Our experience so far. Being a Guest lecture presented at the National Scientific Conference organized by the Nigerian Society of Pharmacognosy (NSP) at Zaria, Nigeria; pages: 11-12.

14. King R and Homsy J (1997). Involving traditional healers in AIDS education and counselling in sub-Saharan Africa: a review. AIDS 11 (Suppl A): S217-S225

15. Kong J M, Goh N K, Chia L S and Chia T F (2003). Recent advances in traditional plant drugs and orchids. Acta Pharmacol. Sin 24, 7-21

16. Liu (2007). The use of herbal medicines in early drug development for the treatment of HIV infections and AIDS. Expert Opin Investig Drugs; 16(9):1355-64. 
17. Liu C, Yang Y, Gange SJ, Weber K, Sharp GB, Wilson TE, Levine A, Robison E, Goparaju L, Gandhi M, Merenstein D (2009). Disclosure of complementary and alternative medicine use to health care providers among HIV-infected women. AIDS Patient Care STDS; 23(11):965-71

18. Lu WB (1997). A report on 8 seronegative converted HIV/AIDS patients with traditional Chinese medicine. Zhongguo Zhong Xi Yi Jie He Za Zhi Zhongguo Zhongxiyi Jiehe Zazhi; 17 (5):271-273. Chinese

19. Matthee G, Wright AD, König G (1999). HIV reverse transcriptase inhibitors of natural origin. Planta Med; 65: 493-506

20. Mbah A U, Udeinya IJ, Shu EN, Chijioke CP, Nubila T, Udeinya F, Muobuike A, Mmuobieri A and Obioma MS( 2007). Fractionated neem leaf extracts is safe and increases CD4+ cell levels in HIV/AIDS patients. America Journal Ther 14 (4):369-74

21. Mills E, Cooper C, Kanfer I (2005). Traditional African medicine in the treatment of HIV, Lancet Infect Dis, 5(8):465-467

22. Minkoff H, Zhong Y, Burk RD, Palefsky JM, Xue X, Watts DH, Levine AM, Wright RL, Colie C, D'Souza G, Massad LS, Strickler HD (2010). Influence of adherent and effective antiretroviral therapy use on human papillomavirus infection and squamous intraepithelial lesions in human immunodeficiency virus-positive women. J Infect Dis; 201(5):681-90

23. Nyika $A(2007)$. Ethical and regulatory issues surrounding African traditional medicine in the context of HIV/AIDS. Dev World Bioeth, 7(1):25-34

24. Onifade AA, Jewell AP, Okesina AB (2010). Phytochemistry and Safety profiles of $\alpha$-zam, an herbal remedy for HIV infection in Nigeria. Tropical Journal of Health; In Press.

25. Talam NC, Gatongi PM, Rotich JK, Kimaiyo S (2009). Adherence to antiretroviral drug therapy by adult patients attending HIV/AIDS clinic at a Kenyan tertiary health institution. East Afr Med J; 86(5):240-243.

26. Tani M, Nagase M, Nishiyama T, Yamamoto T, Matusa R (2002) The effects of long-term herbal treatment for pediatric AIDS, Am J Chin Med.;30(1):51-64.

27. Watson K, Gooderham NJ, Davies DS, Edwards RJ (1999) Interaction of the transactivating protein HIV-1 tat with sulphated polysaccharides,Biochem Pharmacol; 57: 775-783.

28. WHO (2002). Traditional Medicine Strategy 2002-2005. World Health Organisation, Geneva.

29. WHO (2007) Case Definitions of HIV for Surveillance and Revised Clinical Staging and Immunological Classification of HIV-related disease in Adults and Children, www.who.int/hiv/pub/guidelines/HIVstaging 150307.

30. UNAIDS/WHO (2005). AIDS Epidemic Update, UNAIDS, Geneva, Switzerland

31. UNAIDS/WHO (2006). AIDS epidemic update; pp. 1-90.

32. Yu D, Suzuki M, Xie L, Morris-Natschke SL, Lee KH (2003). recent progress in the development of coumarin derivatives as potent anti-HIV agents, Med Res Rev; 23: 322-45 